This article is available open access under a CC BY-ND 4.0 license as part of Berghahn Open Anthro, a subscribe-to-open model for APC-free open access made possible by the journal's subscribers.

\title{
VIOLENCE, RUMOR, AND ELUSIVE TRUST in Mocímboa da Praia, MozambiQue
}

\author{
Ana Margarida Sousa Santos
}

\begin{abstract}
The riots of 2005 in Mocímboa da Praia and the current violent attacks in Cabo Delgado province have resulted in a range of unsettling rumors. This article revisits the riots and their aftermath to make sense of the rumors that have spread since then, fueling fears of violence and uncertainty. These disconcerting rumors are especially rich in what they tell us about the perception of the political Other and the narratives that materialize following violent events. The way in which rumors circulated and were believed or discarded draws a rough picture of the local political arena. This article discusses the elusive nature of trust following sudden violence and addresses the role and relevance of rumors as an obstacle to the creation of peaceful trust relationships.
\end{abstract}

Keywords: Makonde, Mozambique, Mwani, politics, rumor, trust, uncertainty, violence

In late August 2007, I visited Mariano Nakatembo's new house on the outskirts of Mocímboa da Praia, Cabo Delgado. I had often stopped by his old house to see him and his wife Maria. Mariano and Maria are both Makonde veterans of the Mozambican War of Independence (1964-1974). Respected, well-liked, and locally active, they are frequently sought for counsel by their neighborhood president. Like many veterans, Mariano and Maria gradually built a new, larger home, its sizable yard and corrugated metal roof signaling access to a relatively stable income-a state pension awarded to veterans. I found Mariano in the yard, speaking with a friend under the shade of a large mango tree. After his friend's departure, Mariano told me they had talked about the riots sparked by local elections in 2005. Discussing these past events, Mariano's friend spoke of his fear of further violence, remarking on the unfortunate location of his house in Nanduadua, one of the town's oldest neighborhoods where most of 
the violence had occurred. Mariano remarked that he would be safer in the outer neighborhoods called Bairro 30 de Junho and Muengue. He would have a measure of protection offered by the large numbers of Makonde who live there, many of whom are veterans of the war.

An awareness of the "geography of violence" (Das 2013: 799) that marked the riots of 2005 was at the heart of assessments of safety and insecurity. These assessments were informed by a long-held and deep mistrust between the two largest ethnic groups living in Mocímboa, the Makonde and the Mwani, and the rival political parties Frelimo (Frente de Libertação de Moçambique) and Renamo (Resistência Nacional de Moçambique). Concerns about safety and security often centered on news received in the form of rumors-unsubstantiated information that passed by word of mouth and circulated widely in periods of political tension. This article explores the relationship between rumors and fears of violence and uncertainty, examining how the continued circulation of rumors can act as a deterrent to the establishment of peaceful trust relationships between political factions.

Mariano's worries for his friend were born out of personal experience. During the riots that shook Mocímboa in September 2005, and in the days that followed, he took in large numbers of people fleeing violence. By the second anniversary of the riots, he worried that those same people might once again need his assistance and seek shelter with him and Maria. My conversations with Mariano highlighted the widespread anticipation and fear of violence in 2007. A mix of rapidly circulating rumors made my interlocutors wary of a repetition of the violence that had occurred two years prior, stirring fear, anxiety, and suspicion. These conversations emphasized the value placed on rumor as a source of information and as an expression of local interpretations of events. Moreover, rumor intersected with local understandings of politics, social geography, and ethnic and religious divides. Rumors were a reminder of the failure of local politicians to calm the discord between Makonde and Mwani. My interlocutors actively sought out rumors-however disconcerting and disorienting-hoping that they might assist in making sense of local politics and help anticipate potential violence.

This article explores the aftermath of violent riots that took place in 2005 in Mocímboa da Praia, in northern Mozambique. Delving into the rumors that spread in the days and months that followed the violence, I examine how the circulation of unverified information allowed my interlocutors to prepare for possible violent encounters and simultaneously exacerbated the politics of suspicion and the town's deep political fractures. I will argue that rumors take shape in specific ways that have been impacted by long political histories and current events. In making this argument, I suggest that we look at the history of northern Mozambique to understand the relationship between political rumors and the search for certainty in Mocímboa. I begin by discussing theoretical 
approaches to rumor, tracing the long history of ethnographic engagement with unverified news. I then describe the riots of 2005 and offer a brief introduction to the contested political landscape of Mocímboa. Following this, I unpack the dynamics of rumors, highlighting the ways in which they (re)produce historical narratives and destabilize fragile relations of trust, and trace how they reflect existing stereotypes that fuel fear and suspicion. In describing the volatile conditions in which people sought information to coordinate individual and collective actions, I attempt to make sense of the politics of suspicion in Mocímboa and to show how rumors not only breed fear and uncertainty but also illuminate lines of alliance. The combination of a shifting political realm and the potential for violence heightens the need to establish avenues of trust, which I will focus on at the end of the article.

A discussion of the rumors that circulated at the time of my fieldwork (2005-2007) is especially important at the current juncture for what they reveal about the local political dynamics of Cabo Delgado, the northernmost province of Mozambique. This region has been the site of unpredictable, frequent, and increasingly violent attacks since October 2017, especially in the districts of Mocímboa, Palma, Nangade, Muidumbe, and Macomia. In August 2020, Mocímboa fell to insurgents, and the majority of its inhabitants sought refuge in neighboring villages, islands, or the provincial capital Pemba, repeating patterns of escape from earlier conflicts. While the analysis that follows may be of help in understanding the dynamics of the violence that affects the province, and especially Mocímboa, a more detailed discussion of the ongoing violence is beyond the scope of this article.

\section{Rumors and the Political Realm}

In their seminal analysis of rumor, gossip, and witchcraft, Stewart and Strathern (2004: 38-39) define rumor as "unsubstantiated information, true or untrue, that passes by word of mouth, often in wider networks than gossip," and it is in the same vein that I understand rumor throughout the article. While contributing to the 'social production of hate' Das (1998), rumors tell us much about local understandings and the construction of historical narratives and politics (Niehaus 2013) and can be read as a template for local relationships.

In earlier studies, rumor was conceptualized alongside gossip (Gluckman 1963) and understood in relation to social control and stability. Anthropologists have since investigated rumor in relation to a wide range of socio-political configurations-from migration and the consumption of human flesh (Masquelier 2000), the stealing of blood (White 2000), and the traffic of heads (White 1997) to witchcraft and violence (Bonhomme 2012; Israel 2008; Stewart and Strathern 2004) or vast conspiracies (Wagner 2017)—providing a glimpse into how 
narratives can impart meaning to events and social dynamics. Ethnographic and historical explorations of rumor reveal its role as a trigger for riots and rebellion (cf. Osborn 2008; Rudé 1959; Tambiah 1996; Wagner 2017) and show its ability to perpetuate insecurity and uncertainty as contradictory information is passed on (Das 1990, 1998, 2007; Maqsood 2019; Perice 1997; Simons 1995; Sökefeld 2002; Tambiah 1996). Rumors provide a way of understanding power (Fontein 2009; Kirsch 2002; Osborn 2008; Stoler 1992; White 2000), resistance (Guha 1983; Scott 1985), and panic and terror (Perice 1997; Wagner 2017). I build on this well-established research to question what rumors tell us about the mechanisms through which trust is re-established or mistrust grows. To make sense of rumors and their local impact, I consider them within the specific, and complex, historical and social context in which they emerged, examining enduring questions of trust and mistrust at the local level, which are seldom addressed in studies of rumor.

White and Stoler offer valuable insights on the nature of rumor, its transmission, and how to make sense of it historically. White (2000: 86) makes the case for historicizing rumor, pointing out that doing so "may reveal little about the individual life or experiences of the speaker, but contextualized with other rumors by other speakers, it may reveal an intellectual world of fears and fantasies, ideas and claims that have not been studied before. The contradictory elements of rumors can be read to reveal the complications of everyday concerns." Stoler (1992) suggests using rumors ethnographically, especially when trying to make sense of incomplete sources that, like the rumors discussed below, either represent the incoherent nature of rumor or gloss over it.

Determining the veracity of the rumors is largely irrelevant for the purposes of this article (cf. Ellis 1989; Masquelier 2000; Stewart and Strathern 2004), because "regardless of whether we treat rumors as 'snatches of knowledge, truths, and half-truths' ... manufactured memory, or make-believe, we must recognize that rumors are both the process and the product of human imaginings" (Masquelier 2000: 90). I am therefore interested in the ways that rumors express traditional and modern political dynamics, and what they tell us about categorical distinctions and registers of trust and mistrust. Rumors "shaped what people thought they knew, blurring the boundaries between events 'witnessed' and those envisioned" (Stoler 1992: 154), highlighting the importance of understanding "things that never happened" (White 1993: 27) and what they meant to the people for whom they were real. While they may offer "distorting prisms" (Chandavarkar 1998: 9) and be the source of ambivalences and ambiguity (Maqsood 2019; White 2000), rumors are revealing in that "the interpretive possibilities become more complex and intriguing" (Hahn 1997: 124) and emerge as an alternative to official narratives (Kapferer 1992). In trying to ascertain what the rumors reveal about trust and mistrust, I now discuss the riots and the ensuing rumors. 


\section{Rioting and Its Aftermath}

The riots that Mariano and his friend discussed were sparked by a local political contest between Frelimo and Renamo supporters in 2005. The sudden death of Mocímboa's Frelimo council president, Camissa Adamo Abdala, in December 2004 required early elections, which were scheduled for the following May. The campaign was described as both contested and quiet, with Frelimo and Renamo claiming victory before the ballots were cast. The election count was difficult, with up to 13 recounts, and in the end was won by Frelimo's candidate, Amadeu Francisco Pedro. However, the result was contested by Renamo's candidate, Said Assane. After the elections, there were daily demonstrations by Renamo sympathizers at the party's headquarters in Nanduadua. While Pedro was being sworn in as the new president on 5 September, Renamo members enacted a symbolic handover of power to Assane. His followers made their way to Bairro 30 de Junho with the aim of tearing down the cross placed there by the Christians for the Jubilee Year of 2000. They assaulted non-Renamo supporters who crossed their path and were ultimately intercepted by Frelimo supporters from Bairro 30 de Junho on the main road out of Mocímboa. In the early morning hours of 6 September, a large number of Renamo backers gathered close to the Nanduadua neighborhood and started attacking buses and travelers. After the attacks, this group began looting and destroying houses, targeting those where Frelimo members lived and burning others along the way. In Bairro 30 de Junho and Muengue, ${ }^{1}$ Makonde veterans from the anti-colonial war prepared to fight the rioters, but news of incoming police and military stopped them from heading into Nanduadua. This information was false, but it may have averted further violent clashes and was indicative of the rumors that circulated at the time. When the violence ended, 128 houses had been burned or destroyed, 47 people had been taken to the hospital, and there were 12 official deaths. Witnesses suggested that these numbers were low. Before describing the specifics of various rumors, I will discuss the political and social context in which they circulated.

The election and ensuing violence confirmed fractures of social relationships in Mocímboa, highlighting the historical, ethnic, religious, and political rifts that split the town and are distinctive in the political landscape of Cabo Delgado. Although in Mozambique political affiliation is traced more often along regional than ethnic lines (Brito 1995), in Mocímboa ethnicity and political allegiance overlap to some extent, with Makonde largely supporting Frelimo and Mwani supporting Renamo.

Frelimo's dominance in Mozambican politics and its efforts to build a narrative that legitimizes its enduring political control nationally (Borges Coelho 2013; Israel 2013; Sumich 2010, 2016) are well documented. The close association of Frelimo and the country's independence, as well as the history of the 
anti-colonial war in Cabo Delgado, are directly connected to the overwhelming support it enjoys in most of Cabo Delgado (Israel 2006, 2010; Santos 2011; West 2005). Frelimo has traditionally won national and local elections in Cabo Delgado by comfortable margins, maintaining a strong support base among the Makonde (cf. Israel 2006). It is in this context that Mocímboa is unusual.

No stranger to turmoil, Mocímboa is the site of prolonged and often violent political change: from its establishment as a military center by the Portuguese in 1891 (Conceição 2006: 77) to the exploitative regime of the Nyassa Company (1891-1929) (Vail 1976), the Portuguese colonial administration, the War of Independence (1964-1974), and the Mozambican Civil War (1977-1992). ${ }^{2}$ It experienced relative peace after the civil war ended when, after long negotiations, Frelimo and Renamo signed peace agreements in Rome (Rocca 1998), implementing political, economic, and social changes (West and Myers 1996: 28). Peace also brought large numbers of returnees (Kingdon 2002; Panzer 2013; Tague 2012; West 2005); this reshaped the social geography of Cabo Delgado, greatly increased the population of Mocímboa, and made the district one of the most politically competitive in Cabo Delgado. Frelimo won every local electoral contest since Mocímboa became a municipality in 1998 (Mpalume 2003), but with a consistently narrow margin.

The division between Frelimo/Makonde and Renamo/Mwani led to bitter electoral contests. Like elsewhere in the country, Renamo effectively attracted support among those alienated by Frelimo (Bertelsen 2009; Dinerman 2006; Geffray 1991; Igreja 2008, 2010; Manning 1998). Frelimo's post-independence policies strongly alienated the Mwani, who were perceived locally as aligned with the Portuguese colonial power and contributing little to the fight for the country's independence. Research by Bonate $(2009,2013)$ shows the extent of the participation of the northern Muslim population in the war and establishes that resistance was far greater than my interlocutors believed. The Mwani expressed bitterness at being continually excluded from politics following independence-despite the rights afforded to them by their autochthonous status along the coast-and voiced long-held resentment over the concentration of political power among the Frelimo-backing Makonde. The Makonde emphasized their support for Frelimo and their role in the anti-colonial war, framing their access to state power as legitimate.

The riots, marked by increased rivalry, prolonged and intense political agitation, and the constant use of divisive rhetoric pitting Renamo/Mwani against Frelimo/Makonde, were fueled by rumors. As I will now describe, the differing rumors are especially rich in what they tell us about the perception of the political Other and how the past underscores the narratives that emerge following violent events, which have the potential to draw people together or to divide them along old lines of allegiance, furthering past resentments. I will then consider both the content of the rumors and the context in which they 
were shared and discuss the ways in which they offered a semblance of control amid deep uncertainty.

\section{The Nature of Rumors}

The riots discussed above were bookended by months of protest and anxiety. Arising in an ambiguous context, the rumors added to the uncertainty and fear, building on existing antagonism between Makonde and Mwani, feeding off spatial understandings of ethnicity and belonging, exacerbating the town's deep and enduring divides, and emphasizing the fragility of the state. The rumors spread quickly and changed daily in the months after the riots despite their unreliable origin and dubious veracity. Reminding people of past violence, rumors collapsed the boundaries between past and present, politics and ethnicity. Mocímboa's inhabitants sought whatever information they could find, debating and assessing it based on prior expectations and existing oppositions in order to make individual and collective decisions.

I encountered the first rumors when I arrived in Pemba, the capital of Cabo Delgado, to begin fieldwork on the day that the riots began. The city was abuzz with contradictory details, and as I was unable to get reliable information about the events, I listened to all and any news. The riots were a frequent topic of conversation in Pemba, but there was very little information to build on and no way of ascertaining its veracity. There was the risk of additional violent clashes, and it was in this context that I weighed the options regarding my upcoming fieldwork in Mocímboa. A large number of my interlocutors in Pemba, who were as uncertain about the events in Mocímboa as I was, advised me to wait a few months or to go elsewhere. In the days that followed, I waited and listened to rumors, small scraps of information that failed to shed light on the situation. My unfamiliarity with the nuances of the local political context and my inability to evaluate their potential plausibility made these rumors especially perplexing.

One of the most persistent rumors referred to people leaving town-the Makonde going inland, returning to their traditional territory on the plateau, and the Mwani heading toward the sea, seeking refuge in the islands off the bay. The fact that the rumors of impending violence were taken seriously enough to prompt flight to the islands and the interior suggests the close interplay between rumor and local understandings of space and belonging, history and politics (cf. Stewart and Strathern 2004), and points to the search for safety and certainty. The immediate action in response to unverified news reveals the extent of the fear and the proactive choices made to avoid a potential repeat of the violence. Those who ran from town did so not because of ongoing violence, but because the rumors were generally alarming. Some of these people, I was told, never returned, remaining in their ancestral villages for fear of renewed 
violence. Most eventually made their way back after carefully evaluating information from friends and family and perceiving their town as mostly peaceful. For some people, this took a while, and they did not return until months after the riots. One of the fruit sellers in a large market on the seashore, who was a well-known Renamo supporter, did not appear until six months had passed. He had been away so long that he was believed to have died during the riots.

To counter the rumors of impending violent confrontations that caused people to flee, news was spread that the army and police would soon arrive in large numbers to ensure peace and protect the town's population. This news was quickly contradicted by reports that the police and the armed forces would not intervene, and that there had been no official call for the armed forces. There were also rumors about different delegations of politicians, from both Frelimo and Renamo, who were due to visit Mocímboa.

Because the riots followed elections that related to the Renamo-Frelimo rivalry, there were constant allusions to the civil war that stirred fears not long put to rest. The return of the violence "brings back to life the ghosts of the past-and once again present violence mirroring violence past dominates major national discourses and informs positions" (Bertelsen 2016a: 195). While speaking with a wide range of people in Pemba (political representatives, church leaders, NGO workers, and hospital staff), whose knowledge of local politics was far greater than mine, I was struck by how little was actually established, and how much of what was passed on depended on guesswork. Listening to rumors became a way of keeping an ear to the ground, of paying attention to changes in the flow of information. In the days that followed the riots, a flurry of political activity took place in Pemba-visits from Frelimo officials, meetings of government members, and political addresses from ministers. At the same time, very few people made their way to Mocímboa to evaluate the fallout from the riots in situ. The Aga Khan Foundation delegation in Pemba sent a group of representatives who met with local leaders and a focus group. However, their conclusions did not extend beyond trying to ascertain the immediate causes of the conflict and were not shared widely, and thus did nothing to dispel rumors.

Simons (1995) similarly discusses the importance of rumor and the need to gather and consider diverse and sometimes contradictory scraps of information. In an effort to get data, the constant reliance on networks (those whom one knew and got news from) affected one's view of the conflict and emphasized distinctive concerns. Likewise, by listening to rumors I began painting a picture of Mocímboa, while being acutely aware of how partial it was. What I heard was a deeply political account, one that more often than not accepted official narratives without question and highlighted the illegitimacy of the violence and the unreasonableness of contesting the election results in such a way.

I was not the only one relying on rumors. Even those who had been in Mocímboa at the time and had witnessed the riots first-hand (so to speak) 
listened for rumors. When I met Sister Délcia, one of four Catholic sisters who lived in Mocímboa, I got a partial account of events. Having been in town when the riots occurred, she had remained at home, away from the unfolding violence, but was able to piece together what had happened from friends who lived in Nanduadua and Bairro 30 de Junho. While it was possible for her to establish a timeline of the riots and get a sense of the destruction they caused, the uncertainty of the days that followed made her as eager to listen to rumor as I was.

When I arrived in Mocímboa less than two weeks after the riots, the tension and fear were still palpable, creating an anxious and agitated atmosphere. Once there, I began again to seek out news and rumors. There were a number of privileged spaces where news was widely shared. Local markets, small tea stalls, bars, mosques and churches, public transport, places showing films in the evening, and weekly political and neighborhood meetings-all these presented opportunities for news to be passed on and discussed. The news was also discussed at home between family and friends and examined for clues about what might be in store in the near future. Rumors were exchanged as valuable, if unreliable, information, full of meaning (cf. Kapferer 1992). These constant exchanges of information had a perverse effect, increasing fear and anxiety along with the potential for more violence. Although not directly responsible for violence, rumors can fuel it, creating an environment of heightened anxiety (Osborn 2008).

Shortly after my arrival, I visited Nanduadua, the neighborhood where whole rows of houses had been burned to the ground, leaving their inhabitants destitute. Coming in from the fork in the road where the early confrontations near the buses and chapas $^{3}$ took place, I walked past the eerily silent Renamo headquarters, where months of protest had been enacted, and a number of shops toward the area where most of the houses had been burned. I spoke with those whose homes had been reduced to rubble while assisting a local group in doing an inventory of the damage. This effort was in response to vague government promises about building and reconstruction materials that were circulating at the time, and in the hope of getting the supplies to families who needed them before too much time had passed. There were also questions about whether this help would arrive. Those whose houses and possessions had been destroyed, and who now faced a rainy season without a roof over their heads, had serious concerns about whether the support would materialize before the rains started, allowing them to rebuild their homes in time. The government's promise to supply building materials was fulfilled, but prior to their arrival and distribution, they were discussed in the same terms as any rumors, emphasizing the uncertainty and ambiguity with which they were considered.

The violence of the riots lasted just a few days, but the prevalence of rumor endured. In the early mornings, as I made my way along the main road to one of the outer neighborhoods for interviews and discussed the previous day's 
work with my research assistant, Tissa, we caught up on what happened after work and discussed the news we had heard. We exchanged fresh news, stories, and very often new rumors, for example, about impending visits of political leaders or planned meetings of the opposition, which could become demonstrations and could again be the source of violence. Those conversations allowed us to cross-reference rumors that were spreading in the different neighborhoods where we lived and to get a feel for the evolving situation. We traded information with the acute awareness that it was impossible to verify (cf. Stewart and Strathern 2004), treating it with skepticism. The news we discussed was part of a patchwork of knowledge and guesswork that contributed to anxiety and uncertainty and was used to anticipate potential violence, often considered without eliciting conclusions or inviting interpretation.

In the immediate aftermath of the riots, people feared more violence, and the news focused on the arrival of the police or the army and on those who had successfully escaped the town. Later, however, rumors began to relate primarily to political developments, such as impending visits by high officials from Frelimo or Renamo, reinforcements to Renamo, and future demonstrations. There was a general sense of uncertainty and insecurity in public spaces. The town was full of tension, and discussions about politics, violence, and the repetition of riots constantly took place.

Superficially, the town appeared peaceful by November. However, as time passed, the rumors continued, and I, along with my interlocutors, kept wondering and discussing how much was still to come, or if the conflict had indeed been resolved. There were several occasions when rumor suggested the likelihood of violence. On one such occasion in December 2005, when Afonso Dhlakama, then the leader of Renamo, was expected to visit, a large crowd had gathered near Renamo's headquarters, sprawling on to the main road for nearly a kilometer in the direction of the airport. I was told that in the months before the riots such crowds were not uncommon. Other occasions when there was a spike in rumors coincided with dates marking political celebrations, such as 3 February, the day that celebrates Mozambican heroes, or the day that the new secondary school was inaugurated.

Discussing news candidly and believing in rumors depended on their provenance. Suspicion persisted long past the end of the violence. In the summer of 2007, close to the second anniversary of the riots, new rumors surfaced, causing increased apprehension. This was different from the immediate aftermath of the riots, when the violence was alluded to but often not discussed directly. Two years on, the rumors focused similarly on political developments and referenced the same fears of violence and division. Fear and anxiety fed on them. Some of the Makonde I spoke with were, as they said, steeling themselves for more violence. During meetings held by war veterans, the riots were discussed yet again, and the new rumors were examined. There was fear of 
demonstrations to mark the anniversary of the riots, and that these could lead to a new surge of violence.

Rumors can be read as an expression of fears and anxieties that contribute to the perpetuation of uncertainty; adding to the corrosion of trust, they frame the anticipation of violence and political upheaval. In the case detailed here, the rumors are revealing of local social and political tensions and the shared idioms of power and local politics. They also signal the undercurrent of tensions in the months that followed the riots and the fear of more violence and uncertainty about the future. The political nature of the rumors, reflecting the asymmetrical position of Makonde and Mwani in relation to the state, highlights the deep mistrust in political institutions at the local level despite their efforts to build trust and unity. It was in this context of deep mistrust and the struggle for political legitimacy that the local political leaders embarked on a series of efforts to re-establish trust, as I will discuss below.

\section{Trying to Establish Trust in a Shifting Terrain}

In the aftermath of the riots, local political leaders, especially the recently appointed district administrator, embarked on a series of goodwill campaigns. Aimed at fostering unity between people from different neighborhoods, an effort was made to bring together actors with distinctive political allegiances and ethnic backgrounds in order to assuage the different factions. A few weeks after the riots, the district administrator led a meeting at the town's club with the leaders from different mosques. As we sat on what looked like old school chairs and desks, the district administrator and the local first secretary of Frelimo took turns speaking. Referencing past wars and peace efforts, they stressed the importance of reconciliation and listening to grievances. The new council president was present but did not speak. Notable in their absence from a meeting intended to address the strife that caused the riots, and the uncertainty that followed, were any members of the opposition party, Renamo. It was said that most of the local leaders had escaped to Pemba or farther south and would not be returning. Fear of violent reprisals was said to keep them from coming back to Mocímboa. The meeting was long, formal, and structured around a discussion of the riots, allowing for time to translate the various interventions, ${ }^{4}$ with little hope for a positive outcome. At the end of the meeting, one bag of rice was given to each mosque. The following Sunday, a similar meeting was held with the Catholic community during Mass. The majority of those attending church were Makonde, a large number of whom were involved in the town's political administration and Frelimo. A month later, Eid ul-Fitr was celebrated by a small representative group of Muslim men and women under the trees just outside the main administration building. The 
district administrator, his wife, and representatives of Frelimo took part in the events celebrating the end of Ramadan. The council president, whose election had proved so contentious, was conspicuously absent. The politicians' efforts to calm the situation and make strides toward reconciliation perversely highlighted the enduring instability and fear.

In light of the political nature of the riots and the response of local politicians, largely from Frelimo, it is relevant here to look at how they sought to build trust and safety after the riots. In the months that followed, the most visible representatives from Renamo were absent. They did not appear publicly until they attended a dance competition the following May. At that time, in a show of unity and visibility, they joined the Frelimo leadership in the stands.

The perceived importance of political trust, as understood by the members of the political hierarchy in Mocímboa, and the implicit awareness of it as a public good that would allow for the healing of the local wounds highlighted by the riots, was part of the political efforts and speeches. Yet it was impossible to gauge whether it was ultimately achieved in any tangible way, much less sustained. How can we understand trust in this unstable and fraught context? What does a political narrative of trust conceal?

Trust has long been identified as a common good, the glue that is necessary to bind a cohesive, working society and ensure a degree of predictability and confidence (Mühlfried 2018; Seligman 1998), while its opposite, mistrust, is seen as a corrosive "social acid" (Carey 2017: 2). Trust, doubt, and mistrust have long been absent from ethnographic focus (Yarrow 2018), but recent explorations of trust in relation to risk and uncertainty (Broch-Due and Ystanes 2016; Carrier and Elliott 2018; Cooper and Pratten 2015; Corsín Jiménez 2011; Mühlfried 2018) have yielded compelling analytical insights that can be productively considered in relation to the spread of rumor and its reverberations.

The rumors and continued mistrust in the aftermath of the riots confirm that familiarity is insufficient to ensure certainty and trust (Carey 2017), since "communities in which people continue to engage ... in social boundaries that are situationally specified, unresolved and always in question" (Yarrow 2018: 220) rely on old stereotypes and divides when assessing rumors and in so doing magnify uncertainty. The rumors placed different categories in opposition (outsiders and insiders, owners and guests, autochthons and intruders) within the enduring social, ethnic, religious, and especially political oppositions in Mocímboa, where mistrust flourishes. However, given the limits of this article, I am focusing primarily on efforts intended to build trust in the political system. Local politicians' formal and informal endeavors to establish a measure of trust in the political hierarchy and to bring together opposing groups in the aftermath of the riots should be read within this framework. Their attempts to build trust and rectify long-held divides were not necessarily successful in the long run, but an uneasy peace was achieved for a time. The conflict-laden relationships 
in Mocímboa that preceded the fight for independence, and were compounded and worsened since then, made their task especially arduous.

My research suggests that rumor not only revealed the deep and enduring opposition between different groups in Mocímboa, expressed through references to politics and redefinitions of Otherness, but also tended to intensify existing mistrust. The lack of trust between Makonde and Mwani was not new. Established through a long history of antagonistic encounters, as well as colonial and post-colonial manipulation and marginalization by the state (Conceição 2006; Igreja 2008, 2010; Israel 2020; Medeiros 1997), it came into stark relief immediately after the riots, and once again in the context of the current attacks. The categorical distinction between Makonde and Mwani, while present in accounts from the late nineteenth century (O’Neill 1882, 1883, 1885; West 2004) and narratives of local history, was increasingly sharpened during the colonial period (cf. Southall 1970) and post-independence political developments, and found expression in the divides between Frelimo and Renamo.

Involvement in politics was central in Mocímboa. There was constant reference to meetings to attend and issues that required discussion. Despite this, those involved directly in politics were a small percentage of the population. The people who were the most active in Frelimo, for example, were the men and women who had taken part in the liberation struggle. The participation was generational and gendered-mostly older men and fewer women of the same generation. Younger Makonde, although not politically active, tended to vote Frelimo. Mwani political alignment was marginally less connected to ethnicity. Mwani voters tended to be pro-Renamo, but some high-profile members of Frelimo in Mocímboa were of Mwani origin, among them the local council president. Allegiance to Renamo was chiefly associated with disappointment with Frelimo and long-standing grievances. From a position of dominance in the town and nearby villages, the Mwani had seen the arrival of Makonde in increasing numbers since independence, and especially since the end of the civil war in 1992. These newly arrived Makonde slowly took positions of power within the local and district administrations. With stronger links to the ruling party due to their role in the liberation struggle and the networks that remained from their army days, they were much better positioned at the time of independence to secure posts left by the Portuguese colonial administrators and their local 'collaborators', who by then were considered compromised and were removed from power.

Like elsewhere in the country (cf. Geffray 1991; Manning 2002), this created dissatisfaction and gave rise to Renamo support. In the long run, it also provided fertile ground for deep mistrust and helped to "shape and enable prevailing imaginaries of mistrust, directing them against particular enemies" (Carey 2017: 85). The rumors discussed here and the efforts of local political leaders to re-establish trust illuminate the multiple ways through which trust can be made and unmade, and their impact on attempts to bring stability to a town 
laden with historical conflicts and long-held oppositions. The rumors confirmed existing oppositions and allowed the inhabitants of Mocímboa to navigate (Vigh 2008) the social and political aftermath of the violence, but they undermined the efforts of local political leaders to bring stability and peace.

\section{Rumors, Stereotypes, and the Political Other}

How can these disparate rumors explain the local relationships and politics and the perception of the political Other? The way that the rumors circulated and were believed or discarded can help make sense of local fears and anxieties, drawing a rough picture of the political arena in the aftermath of violence. This picture is by nature incomplete, but it need not be inaccurate. The rumors and the belief or doubt they engendered hinged upon a long-established duality in the occupation of the town, as well as long-held stereotypes that circulated about its inhabitants. Some of these discussions came from a place of perceived marginality and abandonment, both locally and nationally. The chronic and vocal mistrust was expressed through crude ethnic stereotypes; constant discussions about local politics, corruption, and the lack of political accountability; and occasional references to the national political landscape.

The rumors circulating in Mocímboa in the months that followed the riots expressed local concerns with violence, politics, and access to a state that was increasingly seen as associated with one of the groups (Makonde) at the expense of the other (Mwani). These tensions and grievances, often invisible, were expressed through unfounded rumors shared among friends and relatives. They were heard in places as diverse as market stalls, streets, water fountains, churches, and mosques, or were shared at home. Rumor was a way for people to "both concretely experience the threat of political violence and express their concerns about it" (Kirsch 2002: 57; original emphasis) and a way to define personal and group alliances. Distinctions based on ethnicity or known political allegiance and stereotypes fueled the rumors, which generally referred to an identifiable, yet somewhat vague, Other. The visibility and invisibility of protesters and political actors permeated the assessments and informed the rumors spread around the town.

"Renamo supporters are only good for singing and dancing" was a phrase I would hear often from Makonde men and women when discussing local politics. This referred specifically to the months after the elections of May 2005 and before the riots of September, during which large numbers of Renamo supporters gathered under the mango trees behind Renamo's headquarters to protest the results of the municipal elections. It also referenced perceived participation or absence in the anti-colonial war and the fact that Mwani men and women could resort only to protest and did not have real political power or 
hold influential posts in the state administration. Frelimo supporters ${ }^{5}$ described Renamo supporters as prone to creating turmoil, deeply unreliable, and thus unworthy of trust. Those who voted for Renamo were seen as confused at best and were often portrayed as ungrateful for the struggle for independence fought by Frelimo. The dismissive and derogatory expressions were intended to minimize Renamo's political importance, while support for Renamo was disparaged as a mistake or an accident.

This situation, which is not unique to Mocímboa, having been described elsewhere in the country, relates to imagined differences in education and dependability between Frelimo and Renamo supporters and their perceived political legitimacy (Bertelsen 2016b; Igreja 2015; Pearce 2020; Sumich 2013, 2016). In Muidumbe-one of the districts of the interior with a predominantly Makonde population, known as 'the cradle of Frelimo'-supporters of Renamo are either looked down upon or outright threatened (Israel 2006). While support for Renamo in Mocímboa was unquestionable, and at times expressed strongly, my Makonde interlocutors perceived it as less legitimate and harder to understand, referring to Renamo supporters with the expression bandidos armados (armed bandits), coined in the 1980s, to remind listeners that Renamo had no part in fighting for independence. Although a multi-party system is now well established and regular elections are held, for many of Mocímboa's inhabitants Renamo's efforts to attain power are a reminder of its role in the civil war. While Frelimo supporters made their allegiance known by displaying symbols of the party, Renamo supporters were harder to identify at first glance, and those who had protested in the months leading up to the violence were largely invisible afterward.

Yet despite the dismissive tones with which Renamo supporters were referred to, my interlocutors expressed real apprehension when assessing rumors relating to a potential repetition of the riots. During a conversation about local politics and crime with Jaime Januário Punda, the very active president of Bairro 30 de Junho and a strong Frelimo supporter, he abruptly stopped what he was saying, went inside his house, and returned with a bow and arrows, stating that he was ready for whatever might happen. He was not alone in this. I found that the Makonde I knew best were more apprehensive and defensive than in the immediate aftermath of the riots of 2005. They were more willing to discuss the riots and their fears of renewed violence.

\section{Conclusion}

In this article I have considered how rumors emerge during/after violent events, furthering animosity and eroding fragile registers of trust. I have shown how, in the extremely volatile post-riot context of Mocímboa, rumors focused largely on political antagonism and the anticipation of violence, articulating the ingrained 
opposition of local groups at the confluence of politics and events that exacerbated uncertainty. Building on existing political and ethnic animosity between Makonde and Mwani, as well as distinctive languages of belonging and safety, the rumors discussed above reflect an unsettled political realm and the myriad entanglements between trust and mistrust within particular historical trajectories. Moreover, I have shown that the rumors were not just an expression of fear and suspicion, but were part of the dynamics of violence, suggesting that rumors can hinder the efforts to establish peace and security and can deter the development of trust between different political factions, thus perpetuating uncertainty.

Anthropologists have so far developed a rich body of theory on rumor. Previous accounts address the association between rumor, power, and the state and the ways in which rumors undermine, subvert, or express resistance/ support for various forms of state power, especially focusing on what rumor illuminates in periods of political tension (Ellis 1989; Fontein 2009; Kastfelt 1989; Osborn 2008). The analysis in this article examines how rumors spread in uncertain (Fontein 2009: 386) or ambiguous (White 2000: 81) circumstances, highlighting potential dangers, filling the information vacuum, framing narratives of events (Stewart and Strathern 2004), and adding to the uncertainty and insecurity by contributing to the persistence of mistrust. The contradictory rumors that followed the riots emphasized "the sense of ambiguity, uncertainty and anxiety" (Fontein 2009: 387). Their continuous spread, and the fear and uncertainty they caused, underpinned the mistrust in the state and its ability to exercise control in Mocímboa in spite of its efforts to foster dialogue between the different factions. Unlike the rumors discussed by Fontein (2009), in which the state's omnipotence and the ability of the party elite to exercise power were part of the rumors, in Mocímboa the anxiety came from the unpredictability attributed to the opposition party's capability to mobilize its supporters at will.

The rumors discussed here offer insights into local histories of violence and marginalization, often at the intersection between uncertainty and political violence. The rumors largely focused on protest leading to violence, or the arrival of political and military actors. These rumors are revealing of how Mocímboa inhabitants perceived the existing political crisis, the socio-political framework, and relations of power and powerlessness and translated the potential for violence into plausible scenarios (White 2000: 56) mapped onto the town's topography and social landscape. The rumors tell a story of powerlessness, the memory of former violent encounters, conflicting interpretations, and efforts to prepare for more violence by relying on trusted friends and kin. My interlocutors in Mocímboa navigated (Vigh 2008) everyday uncertainty and ambiguity, seeking out news to make sense of a fluid terrain where information was contradictory and unreliable. They examined, discarded, believed, or doubted the rumors they heard, based on assessments of provenance, plausibility, and danger (cf. Stoler 1992; Subramaniam 1999; White 1997). The constant search for news 
was intended to provide a semblance of certainty but instead fostered greater insecurity and panic. Turning to long-standing personal connections and relying on well-established stereotypes, they turned to rumors that fed "on memory and memory on rumor, rumor on memory and memory on violence” (Subramaniam 1999: 104), attaining plausibility from long-held animosity and mistrust. More than an expression of violence, the rumors were part of the dynamics of violence and should be examined as such, reflecting mistrust in times of strife and uncertainty. While the truth value of the rumors can be endlessly debated, and implicitly important, this article shows the interplay between rumors and the making and unmaking of trust, building on local histories and political dynamics and redefining an opposing Other.

In the context of the renewed armed confrontations between Renamo and state forces in central Mozambique and the current insurgency in Cabo Delgado (cf. Morier-Genoud 2020), it is once more relevant to consider the politics of suspicion in Mozambique and the ways in which rumors play into relationships of trust and mistrust. An analysis of the post-war political context of Mozambique can assist in gaining new insights into the dynamics of violence and state-citizen relations, while revealing the ways in which rumors reproduce existing narratives and destabilize fragile registers of trust during violent and uncertain times.

\section{Acknowledgments}

I would first like to thank the people in Mocímboa da Praia, Cabo Delgado, who generously shared their time and stories with me. I am grateful for the invaluable assistance of Eusébio Tissa Kairo during fieldwork. I would like to acknowledge the helpful comments received on earlier versions of this article presented at the University of Manchester and the University of Roehampton. I want to thank Nadine Beckmann, Kirsten Bell, Judith Bovensiepen, and the anonymous reviewers for their thoughtful suggestions on how to improve the article.

Ana Margarida Sousa Santos is a Research Associate at the Institute of Social Sciences, University of Lisbon. She has done extensive research in Cabo Delgado, Mozambique, focusing on the legacies of political violence, memory and history, ownership, and belonging. Her next research project explores the link between personal trauma and collective remembrance of the colonial war in Portugal, combining theoretical approaches from medical anthropology, collective memory, and memorialization. Recent publications include “'It's Not My Story to Tell': Ownership and the Politics of History in Mocímboa da Praia, Mozambique" (Journal of the Royal Anthropological Society, 2021). E-mail: margarida.sousasantos@gmail.com 


\section{Notes}

1. Muengue and Bairro 30 de Junho are newer neighborhoods in Mocímboa, built to accommodate the increase in population following the end of the civil war in 1992. Each neighborhood is different, with distinctive histories, political affiliations, and socio-economic, ethnic, and religious dynamics.

2. The civil war was fought largely in the south and central provinces of Mozambique where the destruction and impact on the population has been well documented (Bertelsen 2016b; Englund 2002; Geffray 1991; Hall 1990; Lubkemann 2008; Morgan 1990; Morier-Genoud et al. 2018; Nordstrom 1997; Vines 1991). The war reached northern Cabo Delgado in the 1980s.

3. Chapas are privately owned minibuses and trucks used for the transport of people to the villages and nearby towns.

4. The district administrator did not speak Kimwane or Shimakonde, and translation into Portuguese was required.

5. Makonde voted overwhelmingly for Frelimo in all the national and local elections that took place after 1992.

\section{References}

Bertelsen, Bjørn Enge. 2009. "Multiple Sovereignties and Summary Justice in Mozambique: A Critique of Some Legal Anthropological Terms.” Social Analysis 53 (3): 123-147.

Bertelsen, Bjørn Enge. 2016a. “Multisemic Speech Genres as Vehicles for Reinscribing Meaning in Post-conflict Societies: A Mozambican Case.” In Violent Reverberations: Global Modalities of Trauma, ed. Vigdis Broch-Due and Bjørn Enge Bertelsen, 193-217. Cham: Palgrave Macmillan.

Bertelsen, Bjørn Enge. 2016b. Violent Becomings: State Formation, Sociality, and Power in Mozambique. New York: Berghahn Books.

Bonate, Liazzat J. K. 2009. "Muslims of Northern Mozambique and the Liberation Movements.” Social Dynamics 35 (2): 280-294. https://doi. org/10.1080/02533950903076378.

Bonate, Liazzat J. K. 2013. "Muslim Memories of the Liberation War in Cabo Delgado.” Kronos 39 (1): 230-256.

Bonhomme, Julien. 2012. "The Dangers of Anonymity: Witchcraft, Rumor, and Modernity in Africa." HAU: Journal of Ethnographic Theory 2 (2): 205-233. https://doi.org/10.14318/hau2.2.012.

Borges Coelho, João Paulo. 2013. "Politics and Contemporary History in Mozambique: A Set of Epistemological Notes.” Kronos 39 (1): 20-31.

Brito, Luis de. 1995. "O comportamento eleitoral nas primeiras eleições multipartidárias em Moçambique” [Electoral behavior in the first multi-party elections in Mozambique]. In Moçambique: Eleições, democracia e desenvolvimento [Mozambique: Elections, democracy, and development], ed. Brazão Mazula, 473-499. Maputo: Inter-Africa Group. 
Broch-Due, Vigdis, and Margit Ystanes, eds. 2016. Trusting and Its Tribulations: Interdisciplinary Engagements with Intimacy, Sociality and Trust. New York: Berghahn Books.

Carey, Matthew. 2017. Mistrust: An Ethnographic Theory. Chicago: HAU Books. Carrier, Neil, and Hannah Elliott. 2018. "Entrust We Must: The Role of 'Trust' in Somali Economic Life.” DIIS Working Paper No. 2018:2. ISBN 978-87-7605-912-5. Danish Institute for International Studies (DIIS), Copenhagen.

Chandavarkar, Rajnarayan. 1998. Imperial Power and Popular Politics: Class, Resistance and the State in India, c. 1850-1950. Cambridge: Cambridge University Press.

Conceição, António Rafael. 2006. Entre o mar e a terra: Situações identitárias do Norte de Moçambique (Cabo Delgado). [Between the sea and the land: Identity in northern Mozambique (Cabo Delgado). Maputo: Promédia.

Cooper, Elizabeth, and David Pratten. 2015. "Ethnographies of Uncertainty in Africa: An Introduction.” In Ethnographies of Uncertainty in Africa, ed. Elizabeth Cooper and David Pratten, 1-16. London: Palgrave Macmillan.

Corsín Jiménez, Alberto. 2011. “Trust in Anthropology.” Anthropological Theory 11(2): 177-196. https://doi.org/10.1177/1463499611407392.

Das, Veena. 1990. Mirrors of Violence: Communities, Riots and Survivors in South Asia. Oxford: Oxford University Press.

Das, Veena. 1998. "Specificities: Official Narratives, Rumour, and the Social Production of Hate.” Social Identities 4 (1): 109-130. https://doi. org/10.1080/13504639851915.

Das, Veena. 2007. Life and Words: Violence and the Descent into the Ordinary. Berkeley: University of California Press.

Das, Veena. 2013. "Violence, Crisis, and the Everyday." International Journal of Middle East Studies 45 (4): 798-800.

Dinerman, Alice. 2006. Revolution, Counter-Revolution and Revisionism in Postcolonial Africa: The Case of Mozambique, 1975-1994. London: Routledge.

Ellis, Stephen. 1989. “Tuning in to Pavement Radio.” African Affairs 88 (352): 321-330.

Englund, Harri. 2002. From War to Peace on the Mozambique-Malawi Borderland. Edinburgh: Edinburgh University Press.

Fontein, Joost. 2009. “Anticipating the 'Tsunami’: Rumours, Planning and the Arbitrary State in Zimbabwe.” Africa 79 (3): 369-398.

Geffray, Christian. 1991. A causa das armas: Antropologia da guerra contemporânea em Moçambique [The arms cause: Anthropology of the contemporay war in Mozambique]. Trans. Adelaide Odete Ferreira. Porto: Edições Afrontamento.

Gluckman, Max. 1963. "Papers in Honor of Melville J. Herskovits: Gossip and Scandal.” Current Anthropology 4 (3): 307-316. https://doi.org/10.1086/200378.

Guha, Ranajit. 1983. Elementary Aspects of Peasant Insurgency in Colonial India. Delhi: Oxford University Press.

Hahn, Steven. 1997. “'Extravagant Expectations’ of Freedom: Rumour, Political Struggle, and the Christmas Insurrection Scare of 1865 in the American South.” Past \& Present 157: 122-158. 
Hall, Margaret. 1990. "The Mozambican National Resistance Movement (RENAMO): A Study in the Destruction of an African Country.” Africa 6 (1): 39-68. https:// doi.org/10.2307/1160426.

Igreja, Victor. 2008. "Memories as Weapons: The Politics of Peace and Silence in Post-Civil War Mozambique.” Journal of Southern African Studies 34 (3): 539-556. https://doi.org/10.1080/03057070802259720.

Igreja, Victor. 2010. “Frelimo’s Political Ruling through Violence and Memory in Postcolonial Mozambique.” Journal of Southern African Studies 36 (4): 781799. https://doi.org/10.1080/03057070.2010.527636.

Igreja, Victor. 2015. "Amnesty Law, Political Struggles for Legitimacy and Violence in Mozambique." International Journal of Transitional Justice 9 (2): 239-258. https://doi.org/10.1093/ijtj/ijv004.

Israel, Paolo. 2006. “'Kumungalela Guebuza’: The Mozambican General Election of 2004 in Muidumbe and the Roots of the Loyalty of Makonde People to Frelimo." Lusotopie 13 (2): 103-125.

Israel, Paolo. 2008. "Déchirures et rumeurs: La chasse au sorcier et l'héritage idéologique de la révolution socialiste au Mozambique (Muidumbe, 2002-2003)" [Lacerations and rumours: Witch-hunting and the ideological legacy of the Socialist Revolution in Mozambique (Muidumbe, 2002-2003)]. Cahiers d'Études Africaines 48 (189-190): 209-236. https://www.jstor.org/ stable/40379916.

Israel, Paolo. 2010. “The Formulaic Revolution: Song and the 'Popular Memory' of the Mozambican Liberation Struggle.” Cahiers d'Études Africaines 50 (197): 181-216.

Israel, Paolo. 2013. "A Loosening Grip: The Liberation Script in Mozambican History." Kronos 39 (1): 10-19.

Israel, Paolo. 2020. “The Mueda Massacre Retold: The 'Matter of Return' in Portuguese Colonial Intelligence.” Journal of Southern African Studies 46 (5): 1009-1036. https://doi.org/10.1080/03057070.2020.1805854.

Kapferer, Jean-Nöel. 1992. “How Rumors Are Born.” Society 29 (5): 53-60.

Kastfelt, Niels. 1989. "Rumours of Maitatsine: A Note on Political Culture in Northern Nigeria.” African Affairs 88 (350): 83-90. https://www.jstor.org/ stable/722600.

Kingdon, Zachary. 2002. A Host of Devils: The History and Context of the Making of Makonde Spirit Sculpture. London: Routledge.

Kirsch, Stuart. 2002. "Rumour and Other Narratives of Political Violence in West Papua." Critique of Anthropology 22 (1): 53-79. https://doi.org/10.1177/03082 75X020220010301.

Lubkemann, Stephen C. 2008. Culture in Chaos: An Anthropology of the Social Condition in War. Chicago: University of Chicago Press.

Manning, Carrie. 1998. "Constructing Opposition in Mozambique: Renamo as Political Party.” Journal of Southern African Studies 24 (1): 161-189. https:// doi.org/10.1080/03057079808708571.

Manning, Carrie. 2002. The Politics of Peace in Mozambique: Post-Conflict Democratization, 1992-2000. Westport, CT: Praeger Publishers. 
Maqsood, Ammara. 2019. "The Social Life of Rumors: Uncertainty in Everyday Encounters between the Military, Taliban, and Tribal Pashtun in Pakistan.” Comparative Studies of South Asia, Africa and the Middle East 39 (3): 462-474. https://doi.org/10.1215/1089201X-7885414.

Masquelier, Adeline. 2000. "Of Headhunters and Cannibals: Migrancy, Labor, and Consumption in the Mawri Imagination.” Cultural Anthropology 15 (1): 84-126.

Medeiros, Eduardo. 1997. História de Cabo Delgado e do Niassa (c. 1836-1929) [The history of Cabo Delgado and Niassa]. Maputo: Central Impressora.

Morgan, Glenda. 1990. "Violence in Mozambique: Towards an Understanding of Renamo.” Journal of Modern African Studies 28 (4): 603-619.

Morier-Genoud, Eric. 2020. "The Jihadi Insurgency in Mozambique: Origins, Nature and Beginning.” Journal of Eastern African Studies 14 (3): 396-412. https://doi.org/10.1080/17531055.2020.1789271.

Morier-Genoud, Eric, Michel Cahen, and Domingos Manuel do Rosário, eds. 2018. The War Within: New Perspectives on the Civil War in Mozambique, 1976-1992. London: James Currey.

Mpalume, Estevão Jaime. 2003. História da vila de Mocímboa da Praia: 1998, ano da criação do município [History of Mocímboa da Praia: 1998, year of the creation of the municipality]. Secretariado de Coordenação Pastoral de Pemba.

Mühlfried, Florian, ed. 2018. Mistrust: Ethnographic Approximations. Bielefeld: Transcript Verlag.

Niehaus, Isak. 2013. "Confronting Uncertainty: Anthropology and Zones of the Extraordinary.” American Ethnologist 40 (4): 651-660. https://doi.org/10.1111/ amet.12045.

Nordstrom, Carolyn. 1997. A Different Kind of War Story. Philadelphia: University of Pennsylvania Press.

O’Neill, Henry E. 1882. A Three Months' Journey in the Makua and Lomwe Countries. London: Royal Geographical Society.

O’Neill, Henry E. 1883. “Journey in the District West of Cape Delgado Bay, Sept.Oct. 1882." Proceedings of the Royal Geographical Society and Monthly Record of Geography 5: 393-404.

O’Neill, Henry E. 1885. The Mozambique and Nyassa Slave Trade. London: British and Foreign Anti-Slavery Society.

Osborn, Michelle. 2008. "Fuelling the Flames: Rumour and Politics in Kibera.” Journal of Eastern African Studies 2 (2): 315-327. https://doi. org/10.1080/17531050802094836.

Panzer, Michael G. 2013. "Building a Revolutionary Constituency: Mozambican Refugees and the Development of the FRELIMO Proto-State, 1964-1968." Social Dynamics 39 (1): 5-23. https://doi.org/10.1080/02533952.2013.771488.

Pearce, Justin. 2020. “History, Legitimacy, and Renamo’s Return to Arms in Central Mozambique.” Africa 90 (4): 774-795. https://doi.org/10.1017/ S0001972020000315.

Perice, Glen A. 1997. "Rumors and Politics in Haiti." Anthropological Quarterly 70 (1): 1-10. https://doi.org/10.2307/3317797. 
Rocca, Roberto. 1998. Moçambique da Guerra à Paz: História de uma Mediação Insólita [Mozambique from war to peace: History of an unusual mediation]. Maputo: Livraria Universitária, Universidade Eduardo Mondlane.

Rudé, George. 1959. The Crowd in the French Revolution. Oxford: Clarendon Press.

Santos, Ana M. S. 2011. "History, Memory and Violence: Changing Patterns of Group Relationship in Mocímboa da Praia, Mozambique.” PhD diss., University of Oxford.

Scott, James C. 1985. Weapons of the Weak: Everyday Forms of Peasant Resistance. New Haven, CT: Yale University Press.

Seligman, Adam B. 1998. "Trust and Sociability: On the Limits of Confidence and Role Expectations.” American Journal of Economics and Sociology 57 (4): 391-404. https://doi.org/10.1111/j.1536-7150.1998.tb03372.x.

Simons, Anna. 1995. “The Beginning of the End.” In Fieldwork under Fire: Contemporary Studies of Violence and Survival, ed. Carolyn Nordstrom and Antonius C. G. M. Robben, 42-60. Berkeley: University of California Press.

Sökefeld, Martin. 2002. "Rumours and Politics on the Northern Frontier: The British, Pakhtun Wali and Yaghestan.” Modern Asian Studies 36 (2): 299-340. https://doi.org/10.1017/S0026749X02002020.

Southall, Aidan W. 1970. "The Illusion of Tribe.” Journal of Asian and African Studies 5 (1-2): 28-50. https://doi.org/10.1163/15685217-90007037.

Stewart, Pamela J., and Andrew Strathern. 2004. Witchcraft, Sorcery, Rumors, and Gossip. Cambridge: Cambridge University Press.

Stoler, Ann Laura. 1992. “'In Cold Blood': Hierarchies of Credibility and the Politics of Colonial Narratives.” Representations 37: 151-189.

Subramaniam, Radhika. 1999. "Culture of Suspicion: Riots and Rumor in Bombay, 1992-1993." Transforming Anthropology 8 (1-2): 97-110.

Sumich, Jason. 2010. "The Party and the State: Frelimo and Social Stratification in Post-socialist Mozambique.” Development and Change 41 (4): 679-698. https://doi.org/10.1111/j.1467-7660.2010.01653.x.

Sumich, Jason. 2013. "Tenuous Belonging: Citizenship and Democracy in Mozambique.” Social Analysis 57 (2): 99-116. https://doi.org/10.3167/sa.2013.570206.

Sumich, Jason. 2016. “The Uncertainty of Prosperity: Dependence and the Politics of Middle-Class Privilege in Maputo.” Ethnos 81 (5): 821-841. https://doi.org/1 $0.1080 / 00141844.2014 .1002860$.

Tague, Joanna. 2012. "A War to Build the Nation: Mozambican Refugees, Rural Development, and State Sovereignty in Tanzania, 1964-1975.” PhD diss., University of California, Davis.

Tambiah, Stanley J. 1996. Leveling Crowds: Ethnonationalist Conflicts and Collective Violence in South Asia. Berkeley: University of California Press.

Vail, Leroy. 1976. “Mozambique’s Chartered Companies: The Rule of the Feeble.” Journal of African History 17 (3): 389-416.

Vigh, Henrik. 2008. "Crisis and Chronicity: Anthropological Perspectives on Continuous Conflict and Decline.” Ethnos 73 (1): 5-24. https://doi. org/10.1080/00141840801927509. 
Vines, Alex. 1991. RENAMO: Terrorism in Mozambique. Bloomington: Indiana University Press.

Wagner, Kim A. 2017. Rumours and Rebels: A New History of the Indian Uprising of 1857. Oxford: Peter Lang.

West, Harry G. 2004. "Villains, Victims, or Makonde in the Making? Reading the Explorer Henry O'Neill and Listening to the Headman Lishehe.” Ethnohistory 51 (1): 1-43. https://doi.org/10.1215/00141801-51-1-1.

West, Harry G. 2005. Kupilikula: Governance and the Invisible Realm in Mozambique. Chicago: University of Chicago Press.

West, Harry G., and Gregory W. Myers. 1996. "A Piece of Land in a Land of Peace? State Farm Divestiture in Mozambique.” Journal of Modern African Studies 34 (1): 27-51.

White, Luise. 1993. "Cars Out of Place: Vampires, Technology, and Labor in East and Central Africa." Representations 43: 27-50.

White, Luise 1997. "The Traffic in Heads: Bodies, Borders and the Articulation of Regional Histories.” Journal of Southern African Studies 23 (2): 325-338. https://doi.org/10.1080/03057079708708540.

White, Luise. 2000. Speaking with Vampires: Rumor and History in Colonial Africa. Berkeley: University of California Press.

Yarrow, Thomas. 2018. “Afterword: Mistrust after Truth?” In Mühlfried 2018, 219-224. 